\title{
Cultural Lag Dalam Program Penerimaan Peserta Didik Baru (PPDB) Online Dengan Sistem Zonasi Tahun 2018 Di Sekolah Menengah Atas Negeri 2 Sukoharjo
}

\author{
Oleh :
}

Antonius Rahardityo Adiputra ${ }^{1}$, Ravik Karsidi ${ }^{2}$, Bagus Haryono ${ }^{3}$

\begin{abstract}
Abstrak
Cultural lag merupakan salah satu peristiwa disintegrasi dari reaksi masyarakat terhadap bentuk perubahan sosial. Program Penerimaan Peserta Didik Baru (PPDB) online dengan sistem zonasi ini memberikan dampak cultural lag bagi peserta didik di Sekolah Menengah Atas Negeri 2 Sukoharjo. Penelitian ini bertujuan untuk mengetahui dan menjelaskan cultural lag yang terjadi dalam program PPDB online dengan sistem zonasi tahun 2018 di Sekolah Menengah Atas Negeri 2 Sukoharjo. Penelitian ini adalah penelitian kualitatif dengan menggunakan pendekatan studi kasus pada peserta didik baru di Sekolah Menengah Atas Negeri 2 Sukoharjo. Sumber data primer diperoleh dari hasil wawancara mendalam secara langsung kepada informan. Sumber data sekunder diambil dari buku, jurnal maupun dokumen-dokumen resmi lainnya dari informan. Pemilihan informan dipilih dengan cara purposive non-probability sampling. Tehnik pengumpulan data menggunakan observasi langsung, wawancara mendalam dan dokumentasi. Validitas data menggunakan triangulasi sumber. Teori yang digunakan adalah teori Ogburn tentang kecenderungan dari kebiasaan-kebiasaan sosial dan pola-pola organisasi yang tertinggal di belakang perubahan kebudayaan materiil. Hasil penelitian ini menunjukkan bahwa pada tahun 2017 Kementerian Pendidikan dan Kebudayaan Republik Indonesia mengeluarkan program Penerimaan Peserta Didik Baru (PPDB) online dengan sistem zonasi. Hal yang ingin dicapai pemerintah adalah ingin melakukan reformasi sekolah secara menyeluruh. Sistem zonasi dalam program Penerimaan Peserta Didik Baru (PPDB) online ini menjadi salah satu strategi yang digunakan pemerintah untuk mencapai pemerataan pendidikan secara cepat dan berkualitas. Meskipun saat ini model pendidikan dan pembelajaran sudah masuk di era globalisasi, namun fakta di lapangan menunjukkan bahwa minimnya penguasaan digital dan sosialisasi yang kurang maksimal menyebabkan terjadinya cultural lag pada kalangan peserta didik baru di Sekolah Menengah Atas Negeri 2 Sukoharjo yaitu terhambatnya proses pendaftaran dan banyaknya kesalahan dalam pemilihan sekolah. Hal tersebut mengakibatkan proses Penerimaan Peserta Didik Baru (PPDB) dengan sistem zonasi yang dilakukan secara online di Sekolah Menengah Atas Negeri 2 Sukoharjo tidak maksimal.
\end{abstract}

Kata Kunci : Cultural Lag, Peserta Didik, Zonasi

\footnotetext{
${ }^{1}$ Magister Sosiologi Universitas Sebelas Maret Surakarta,(st twiggy@yahoo.com)

${ }^{2,3}$ Fakultas Ilmu Sosial dan Politik Universitas Sebelas Maret Surakarta,
} 


\section{Pendahuluan}

Indonesia merupakan salah satu negara berkembang yang bangsanya sedang mengupayakan berbagai hal untuk membuat Indonesia menjadi Negara yang lebih maju, salah satunya di bidang pendidikan. Bangsa Indonesia berupaya keras menjadikan Indonesia maju di bidang pendidikan. Sistem pendidikan yang dianut Indonesia tak lepas dari sistem pendidikan yang tentunya mampu membawa bangsa Indonesia kepada kemajuan dan perkembangan. Untuk menciptakan bangsa yang cerdas dan berprestasi ditingkat nasional maupun internasional, hal pertama yang dilakukan tentunya adalah terus memperbaiki sistem pendidikan yang ada di Indonesia. Hal tersebut juga mampu menjawab tantangan zaman yang selalu berubah.

Sebagaimana yang tertera dalam visi dan misi Sistem Pendidikan Nasional yang tertuang dalam Undang-Undang Republik Indonesia Nomor 20 Tahun 2003 Tentang SISDIKNAS yang berbunyi sebagai berikut :

"Terwujudnya sistem pendidikan sebagai pranata sosial yang kuat dan berwibawa untuk memberdayakan swmua warga Negara Indonesia berkembang menjadi manusia yang berkualitas sehingga mampu dan proaktif menjawab tantangan zaman yang berubah".

Adapun misi yang diemban oleh SISDIKNAS adalah sebagai berikut :

"Mengupayakan perluasan dan pemerataan kesempatan memperoleh pendidikan yang bermutu bagi seluruh rakyat".

(Munirah, 2015).

Pasal 1 Undang-Undang Republik Indonesia SISDIKNAS Nomor 20 Tahun 2003 disebutkan bahwa Sistem Pendidikan Nasional adalah keseluruhan komponen pendidikan yang saling terkait secara terpadu untuk mencapai tujuan pendidikan nasional. Berangkat dari bunyi pasal ini dapat diketahui bahwa pendidikan adalah sistem yang merupakan suatu totalitas struktur yang terdiri dari komponen yang saling terkait dan secara bersamaan menuju kepada tercapainya tujuan.

Soetarno (2003) menyebutkan bahwa ada beberapa komponen penting dalam pendidikan nasional di Indonesia, hal tersebut adalah lingkungan, sarana prasarana, sumber daya dan masyarakat yang memiliki kompetensi mumpuni dalam bidang pendidikan. Keseluruhan komponen tersebut harus berjalan beriringan satu sama lain, saling memiliki keterkaitan dan mendukung satu sama lain untuk mencapai tujuan pendidikan sesuai visi misi Sistem Pendidikan Nasional yang berlaku.

Sistem pendidikan nasional yang tertera dalam Undang-Undang Republik Indonesia SISDIKNAS sebagai upaya untuk mengembangkan potensi peserta didik yang mengenyam pendidikan, terutama di sekolah Negeri supaya menjadi manusia yang memiliki iman serta ketaqwaan yang baik kepada Tuhan Yang Maha Esa. Selain itu agar peserta didik menjadi manusia yang memiliki akhlak mulia, berbudi pekerti luhur, sehat jasmani dan rohani, berilmu, cakap, kreatif, aktif, mandiri serta menjadi warga Negara yang demokratis, bertanggungjawab serta bermanfaat bagi nusa dan bangsa Indonesia (Munirah, 2015).

Salah satu untuk mewujudkan visi dan misi SISDIKNAS tersebut, Kementerian Pendidikan dan Kebudayaan mengeluarkan program Penerimaan Peserta Didik Baru (PPDB) yang dilakukan secara online dengan sistem zonasi.

Sekolah yang diselenggarakan oleh pemerintah daerah wajib menerima calon 
peserta didik yang berdomisili pada radius zona terdekat dari sekolah paling sedikit sebesar 90 persen dari total jumlah peserta didik yang diterima. Domisili calon peserta didik tersebut berdasarkan alamat pada kartu keluarga yang diterbitkan paling lambat enam bulan sebelum pelaksanaan Penerimaan Peserta Didik Baru (PPDB) (Jurnal Jendela Pendidikan dan Kebudayaan, XII/Juli 2017 : 3).

Radius zona terdekat ditetapkan oleh pemerintah daerah sesuai dengan kondisi di daerah tersebut. Kemudian sebesar 10\% dari total jumlah peserta didik dibagi menjadi dua kriteria, yaitu 5\% untuk peserta didik yang mengalami perpindahan domisili. Namun, sistem zonasi tersebut tidak berlaku bagi Sekolah Menengah Kejuruan. Sistem zonasi ini hanya berlaku bagi Sekolah Menengah Atas (Jurnal Jendela Pendidikan dan Kebudayaan, XII/Juli 2017).

Penerapan sistem zonasi ini tertuang dalam Peraturan Kementerian Pendidikan dan Kebudayaan Nomor 17 Tahun 2017 Tentang Penerimaan Peserta Didik Baru (PPDB) pada Taman Kanak-Kanak, Sekolah Dasar, Sekolah Menengah Pertama, Sekolah Menengah Atas, Sekolah Menengah Kejuruan, atau Bentuk Lain yang Sederajat. Kementerian Pendidikan dan Kebudayaan (Kemendikbud) sebagai regulator, mengatur sistem zonasi yang harus diterapkan sekolah dalam menerima calon peserta didik baru.

Sistem Penerimaan Peserta Didik Baru (PPDB) yang dilakukan secara online dengan sistem zonasi ini menimbulkan berbagai peristiwa disintegrasi dari reaksi masyarakat. Culture Lag dalam Penerimaan Peserta Didik Baru (PPDB) yang dilakukan secara online dengan sistem zonasi ini tidak dapat dihindari.

Pemerintah membuat sistem ini dengan tujuan untuk mempercepat pemerataan kualitas pendidikan. Anak yang kurang mampu secara ekonomi maupun secara akademik tetap dapat mengakses sekolah yang selama ini diperebutkan oleh peserta didik yang tinggal jauh dari sekolah. Harapannya kelak seluruh sekolah dapat merata secara kualitas.

Namun karena beberapa faktor, seperti ketidaksiapan masyarakat dalam menyambut sistem pendidikan di era globalisasi ini, mengakibatkan sistem Penerimaan Peserta Didik Baru (PPDB) online dengan sistem zonasi ini tidak maksimal.

Berlandaskan latar belakang masalah yang masih menjadi kontroversi ini, peneliti tertarik untuk menggali data kemudian melaporkannya ke dalam bentuk tulisan ilmiah. Agar mampu memberikan rekomendasi untuk pihak-pihak terkait.

\section{Cultural Lag}

Ketertinggalan kebudayaan atau yang lebih dikenal dengan istilah cultural lag memiliki keterlibatan antara dua variabel yang berbeda, namun terjadi di waktu yang sama pada masa tertentu. Dengan adanya inovasi atau penemuan baru, salah satu variabel tersebut berubah lebih cepat daripada variabel yang lain. Apabila laju perubahan bagianbagian yang saling memiliki ketergantungan tersebut berbeda dari satu kebudayaan yang lainnya, maka masyarakat dihadapkan dengan kondisi cultural lag. Kemudian penyesuaian kebudayaan yang lain seringkali kurang memuaskan dan tidak bisa mengejar ketertinggalan kebudayaan yang terjadi. (Sztompka, 2004).

William Orgurn (1950) menyatakan bahwa manusia yang tidak adaptif terhadap perkembangan zaman, yang artinya tidak mampu menyesuaikan dirinya dapat berakibat pada kualitas hidupnya. Dimanapun manusia tumbuh dan berkembang di dalam kehidupan bermasyarakat tentu harus memiliki sikap adaptif, jika tidak, maka akan terjadi cultural lag. 
Munculnya cultural lag (ketimpangan kebudayaan), kondisi ini terjadi pada saat unsur-unsur kebudayaan tidak berkembang secara bersamaan. Salah satu unsur kebudayaan yang satu berkembang lebih cepat dari unsur kebudayaan yang lain, sehingga mengakibatkan unsur kebudayaan yang lain mengalami ketertinggalan.

Biasanya hal ini sulit untuk diperbaiki demi menyamakan perkembangan kebudayaan yang terjadi. Hal mencolok yang terjadi adalah terjadinya ketertinggalan cara berpikir dan bertindak masyarakat terhadap sesuatu dibandingkan dengan pesatnya perkembangan ilmu pengetahuan dan teknologi. Kondisi ini banyak terjadi di berbagai daerah di Indonesia (Ogburn, 1950).

Itulah yang menjadi salah satu penyebab negara Indonesia masih menjadi negara berkembang, belum mumpuni untuk mencapai negara yang maju. Terdapat perbedaan antara kebudaaan material dengan kebudayaan imaterial. Hl tersebut mencakaup Lembaga sosial, nilai dan norma yang ada dalam kehidupan masyarakat Indonesia.

Terjadinya cultural lag dipicu dengan adanya perubahan pada kebudayaan material yang cenderung terlebih dahulu mengalami perkembangan daripada kebudayaan imaterial. Pada proses penyesuaian antara kebudayaan material dan kebudayaan immaterial inilah yang disebut dengan cultural lag. (Supardan, 2009).

\section{Penerimaan Peserta Didik Baru (PPDB)}

Penerimaan Peserta Didik Baru (PPDB) merupakan salah satu mekanisme dari penyelenggaraan pendidikan menjelang tahun ajaran baru dimana terjadinya penyeleksian terhadap calon peserta didik yang dilakukan oleh satuan pendidikan guna diterima sebagai peserta didik dalam satuan pendidikan. Untuk menjalankan sistem pendidikan nasional sesuai peraturan perundang-undangan yang berlaku, setiap sekolah mau tidak mau secara serempak melakukan pelayanan Penerimaan Peserta Didik Baru (PPDB) sistem zonasi. Dan ini hanya berlaku bagi sekolah Negeri saja.

Pemerintah membuat kebijakan tersebut dengan tujuan agar sistem pendidikan nasional di Indonesia sama rata, sehingga tidak ada lagi sebutan sekolah favorit. Dimana sekolah favorit biasanya hanya mampu diduduki oleh peserta didik dengan status sosial tinggi serta tingkat kecerdasan akademis yang baik. Hal tersebut tercantum dalam Peraturan Menteri Pendidikan dan Kebudayaan Republik Indonesia Nomor 14 Tahun 2018 Tentang Penerimaan Peserta Didik Baru (PPDB).

\section{Berdasarkan Peraturan Menteri}

Pendidikan dan Kebudayaan Republik Indonesia Nomor 14 Tahun 2018 Tentang Penerimaan Peserta Didik Baru (PPDB) Bab II Pasal 2 ayat 1 bahwa PPDB bertujuan untuk menjamin penerimaan peserta didik baru berjalan secara objektif, transparan, akuntabel, nondiskriminatif, dan berkeadilan dalam rangka mendorong peningkatan akses layanan pendidikan. Kemudian pada Bab II Pasal 2 ayat 2 menyebutkan bahwa nondiskriminasi sebagaimana dimaksud pada ayat 1 dikecualikan bagi sekolah yang secara khusus melayani peserta didik dari kelompok gender atau agama tertentu.

Selanjutnya dalam Peraturan Menteri Pendidikan dan Kebudayaan Republik Indonesia Nomor 14 Tahun 2018 Tentang Penerimaan Peserta Didik Baru (PPDB) pada Bab III Tentang Tata Cara PPDB Bagian Keempat Tentang Zonasi Pasal 16 Ayat (1) menyebutkan bahwa sekolah yang diselenggarakan oleh Pemerintah Daerah wajib menerima calon peserta didik yang berdomisili pada radius zona terdekat dari sekolah paling sedikit sebesar $90 \%$ (sembilan puluh persen) dari total jumlah keseluruhan peserta didik yang diterima. 
Pasal 16 Ayat (2) menjelaskan bahwa domilisi calon peserta didik sebagaimana dimaksud pada ayat 1 berdasarkan alamat pada kartu keluarga yang diterbitkan paling lambat 6 (enam) bulan sebelum pelaksanaan PPDB. Selanjutnya Pasal 16 Ayat (3) menyebutkan radius zona terdekat sebagaimana dimaksud pada Pasal 16 Ayat (1) ditetapkan oleh pemerintah daerah sesuai dengan kondisi di daerah tersebut berdasarkan :

a. Ketersediaan anak usia sekolah di daerah tersebut; dan

b. Jumlah ketersediaan daya tampung dalam rombongan belajar pada masingmasing sekolah.

Pada Pasal 16 Ayat (4) menjelaskan bahwa dalam menetapkan radius zona sebagaimana dimaksud pada Pasal 16 Ayat (3), pemerintah daerah melibatkan musyawarah atau kelompok kerja kepala sekolah.

Selanjutnya pada Pasal 16 Ayat (5) menegaskan bahwa bagi sekolah yang berada di daerah perbatasan provinsi/kabupaten/kota, ketentuan presentase dan radius zona terdekat sebagaimana dimaksud pada Pasal 16 Ayat (1) dapat ditetapkan melalui kesepakatan secara tertulis antar pemerintah daerah yang saling berbatasan. Terakhir, Pasal 16 Ayat (6) menjelaskan bahwa sekolah yang diselenggarakan oleh pemerintah daerah dapat menerima calon peserta didik melalui :

a. Jalur prestasi yang berdomisili diluar radius zona terdekat dari sekolah paling banyak $5 \%$ (lima persen) dari total jumlah keseluruhan peserta didik yang diterima; dan

b. Jalur bagi calon peserta didik yang berdomisili diluar zona terdekat dari sekolah dengan alasan khusus meliputi perpindahan domisili orangtua/wali peserta didik atau terjadi bencana alam/sosial, paling banyak $5 \%$ (lima persen) dari total jumlah keseluruhan peserta didik yang diterima.

Pelaksanaan Penerimaan Peserta Didik Baru (PPDB) offline terdapat beberapa jalur, yaitu jalur Prestasi, jalur Mitra Warga, jalur Bidik Misi, dan Jalur Inklusif. Jalur prestasi yaitu bagi calon peserta didik yang memiliki prestasi baik di bidang akademis maupun non akademis. Jalur mitra warga yaitu untuk calon peserta didik yang berasal dari keluarga kurang mampu. Jalur bidik misi yaitu biaya pendidikan peserta didik miskin yang berprestasi.

Sedangkan jalur inklusif yaitu Sedangkan pada pelaksanaan Penerimaan Peserta Didik Baru (PPDB) online yaitu melalui laman (website) resmi Penerimaan Peserta Didik Baru (PPDB) pada masingmasing daerah. Sekolah yang diselenggarakan oleh pemerintah wajib mengumumkan secara terbuka proses pelaksanaan dan informasi Penerimaan Peserta Didik Baru (PPDB), antara lain terkait persyaratan, seleksi, daya tampung, dan hasil penerimaan peserta didik baru (https://www.kemdikbud.go.id/).

Dalam Pertunjuk Teknis Penerimaan Peserta Didik Baru (PPDB) SMA Negeri dan SMK Negeri Jateng Tahun Pelajaran 2018/2019 menyebutkan bahwa penyelenggaraan Penerimaan Peserta Didik Baru (PPDB) pada Sekolah Menengah Atas Negeri dan Sekolah Menengah Kejuruan Negeri di Provinsi Jawa Tengah Tahun Pelajaran 2018/2019 didasarkan pada prinsipprinsip sebagai berikut :

a. Obyektif, artinya pelaksanaan Penerimaan Peserta Didik Baru (PPDB) sistem zonasi harus adil dan sama rata.

b. Transparan, artinya untuk menghindari kemungkinan penyimpangan yang terjadi maka pelaksanaan Penerimaan Peserta Didik Baru (PPDB) sistem zonasi bersifat terbuka dan dapat 
diketahui oleh masyarakat termasuk orang tua peserta didik baru.

c. Akuntabel, artinya Penerimaan Peserta Didik Baru (PPDB) sistem zonasi mulai dari prosedural, pelaksanaan hingga hasilnya dapat dipertanggungjawabkan.

d. Tidak diskriminatif, artinya setiap warga negara yang berusia sekolah dapat mengikuti program pendidikan pada sekolah Negeri di wilayah Negara Kesatuan Republik Indonesia tanpa membedakan agama, golongan, status sosial (kondisi ekonomi, suku dan daerah asal.

\section{Zonasi}

Sistem zonasi ini merupakan suatu sistem pendidikan nasional di Indonesia yang mengharuskan sekolah Negeri untuk menerima semua calon peserta didik baru mendaftar sesuai zonasinya tanpa terkecuali. Hal ini juga mengarahkan siswa untuk mendaftar di sekolah yang terdekat dengan domisilinya atau alamat yang tertera pada Kartu Keluarga. Dengan demikian dapat meminimalisir peserta didik yang memiliki keunggulan di bidang akademik terkumpul di satu sekolah yang selama ini disebut sebagai sekolah favorit. Sistem zonasi ini berlaku untuk tingka Sekolah Dasar, Sekolah Menengah Pertama dan Sekolah Menengah Atas sederajat Negeri yang berada di bawah naungan langsung Kementerian Pendidikan dan Kebudayaan Republik Indonesia (Rosdiana, 2017).

Sebelum diterapkannya sistem zonasi ini dilakukan dengan menggunakan nilai tertinggi yang berasal dari nilai evaluasi belajar murni (NEM). Hal ini mengakibatkan munculnya istilah sekolah favorit. Istilah inilah yang membuat para siswa baru berlomba-lomba untuk dapat masuk di sekolah yang dicap favorit tersebut sehingga berdampak negatif bagi sekolah-sekolah yang kurang favorit akibat rendahnya siswa baru yang mendaftar dan akhirnya menjadi kekurangan murid (Rosdiana, 2017).

Zonasi merujuk pada pembagian wilayah, yang menjadi pertimbangan dalam sistem zonasi ini adalah daya tamping sekolah Negeri dengan jumlah peserta didik baru di satu wilayah tertentu yang merupakan lulusan Sekolah Menengah Pertama atau sederajat. Klasifikasi zonasi terdiri dari (a) Zona 1, (b) Zona 2, (c) di luar zona. Batasan wilayah zonasi dimaksud adalah :

a. Zona 1 adalah wilayah kecamatan di tempat atau lokasi satuan pendidikan berada dan/atau kecamatan lain yang berbatasan langsung dengan satuan pendidikan yang bersangkutan baik di dalam maupun di luar kabupaten/kota/provinsi yang ditetapkan oleh Kepala Dinas.

b. Zona 2 adalah wilayah di luar zona 1 dan berada dalam satu kabupaten/kota dengan satuan pendidikan yang bersangkutan.

c. Luar zona adalah wilayah di luar ketentuan zona 1 dan zona 2 di dalam satu wilayah provinsi dan/atau luar provinsi Jawa Tengah.

Ketentuan zonasi dalam Penerimaan Peserta Didik Baru (PPDB) diatur sebagai berikut :

a. Penerimaan Peserta Didik Baru dalam zona 1 paling sedikit $50 \%$ dari daya tampung satuan pendidikan, dan apabila ketentuan ini tidak terpenuhi dapat dipenuhi dari calon peserta didik yang berasal dari zona 2 .

b. Penerimaan Peserta Didik Baru dalam zona 2 paling sedikit $40 \%$ dari daya tampung satuan pendidikan, namun ketentuan ini diperbolehkan tidak terpenuhi apabila jumlah calon peserta 
didik pada zona 1 melebihi batas minimal yang telah ditentukan.

c. Penerimaan Peserta Didik Baru (PPDB) luar zona maksimal $10 \%$ dari daya tampung satuan pendidikan. Keseluruhan ketentuan zonasi Penerimaan Peserta Didik Baru (PPDB) ini, tidak berlaku untuk satuan pendidikan Sekolah Menengah Kejuruan. Hanya berlaku untuk Sekolah Menengah Atas (Juknis PPDB SMA Negeri dan SMK Negeri Jateng Tahun Pelajaran 2018/2019).

\section{Teori Cultural Lag}

William F Ogburn, salah satu ilmuwan terkemuka pertama yang telah melakukan penelitian secara rinci mengenai perubahan kebudayaan yang sedang terjadi. Ogburn memiliki beberapa teori yang cukup berpengaruh yaitu mengenai proses terjadinya perubahan kebudayaan yang terjadi di dalam kehidupan bermasyarakat. Teori tersebut terkenal dengan cultural lag, yang memiliki arti ketertinggalan kebudayaan. Bagi Ogburn, cultural lag adalah adanya perbedaan yang mencolok antara kemjuan dari berbagai aspek kebudayaan dalam kehidupan masyarakat.

Teori cultural lag yang dikemukakan oleh Ogburn menjadi sumbangan penting di bidang sosiologi. Konsep cultural lag mengacu pada kecendungan dari habit sosial yang dimiliki masyarakat dan pola-pola organisasi sosial yang tertinggal lebih jauh di belakang (lag behind) terhadap inovasi kebudayaan materiil. Perubahan kebudayaan materiil ini cenderung terus menerus bergulir seiring berjalannya waktu dan mengikuti perubahan zaman yang terjadi secara global. Di sisi lain, perubahan kebudayaan imateriil berjalan lebih lamban dan tidak mampu mengikuti perubahan kebudayaan materiil yang terjadi, pada saat hal ini terjadi di dalam kehidupan bermasyarakat, maka masyarakat tersebut sedang mengalami cultural lag. Dalam karya terkemukanya Social Change with Respect to Culture and Original Nature, Ogburn mengemukakan :

a. Perilaku manusia merupakan produk warisan sosial atau budaya, bukan produk faktor-faktor biologis yang diturunkan lewat keturunan.

b. Kenyataan sosial pada dasarnya terdiri atas pola-pola perilaku individu yang nyata dan konsekuensikonsekuensinya.

c. Perubahan-perubahan kebudayaan materiil terbentang mulai dari penemuan awal. Sedangkan kebudayaan nonmateriil, yang akhirnya berkonsekuensi harus menyesuaikan diri dengan kebudayaan-kebudayaan materiil.

d. Kebudayaan nonmateriil yang tidak mampu mengejar kecepatan perubahan dalam kebudayaan materiil yang terus melaju. Hasilnya adalah suatu ketegangan yang terus meningkat antara budaya materiil dengan nonmateriil (Ogburn, 1950).

Teori cultural lag ini tersusun dari dua variabel penting untuk menunjukkan penyesuaian waktu ataupun masa tertentu. Tetapi karena penemuan baru atau inovasi yang tercipta mendahului variabel lainnya, maka salah satu variabel pasti akan mengalami perubahan atau inovasi baru yang lebih cepat dan lebih baik dari variabel yang lainnya. Dapat dikatakan laju perubahan pada bagianbagian kebudayaan yang saling ketergantungan tersebut tidaklah sama, dalam kondisi ini masyarakat dihadapkan pada situasi cultural lag, yang mana untuk variabelvariabel kebudayaan yang lain akan mengalami kesulitan dalam penyesuaiannya. Sehingga yang terjadi adalah ketidakpuasan dalam pencapaian tujuan yang semula ingin dituju. (Ogburn, 1950). 
Ketidakmampuan dalam menyesuaikan diri yang akhirnya menimbulkan ketidapuasan ini berakibat pada kualitas hidup masyarakat. Bagi Ogburn, terdapat dua jenis penyesuaian sosial, pertama, penyesuaian antara bagianbagian yang terdapat dalam kebudayaan sehingga mampu mampu mencapai tujuan yang sesuai dalam waktu yang bersamaan. Kedua, penyesuaian antara kebudayaan dengan manusia yang hidup di dalam suatu masyarakat. Upaya penyesuaian sosial ini tentu akan mengakibatkan beberapa ketegangan di dalam kehidupan bermasyarakat dan perampasan hak asasi manusia, terjadi kejahatan, serta berbagai patologi sosial yang lainnya. Hal tersebut menunjukkan tandatanda kegagalan sikap adaptif dalam kehidupan sosial. (Ogburn, 1950).

Terjadinya cultural lag dipicu manakala unsur-unsur kebudayaan materiil dan imateriil tidak berkembang secara bersamaan. Kebudayaan materiil cenderung berkembang lebih cepat dibandingkan dengan kebudayaan imateriil, sehingga memicu adanya ketertinggalan kebudayaan. Kondisi ini biasanya terjadi di negara berkembang, salah satunya adalah Republik Indoneisa.

Ogburn, menyampaikan beberapa inti teori materialis, diantaranya :

a. Ketidakpuasan masyarakat terhadap kondisi sosial yang berlaku selama mereka hidup mampu mempengaruhi kondisi pribadi masyarakat, hal inilah yang menjadi penyebab terjadinya perubahan. Baik itu perubahan kebudayaan materiil maupun imateriil.

b. Terdapat hubungan yang berkesinambungan antara unsur-unsur sosial dalam kehidupan bermasyarakat, namun dengan adanya kondisi salah satu unsur kebudayaan telah mengalami kemajuan atau perubahan dan unsur kebudayaan lainnya masih stagnan maka hal tersebut juga menjadi pemicu adanya perubahan sosial.

c. Adanya perubahan dalam kehidupan bermasyarakat, utamanya hal yang berkaitan dengan kebudayaan, maka perubahan acapkali menimbulkan kejutan sosial dengan memunculkan pola-pola pemikiran baru, pola-pola tindakan baru, hingga menciptakan habit baru. Tentu dengan begitu terjadi berbagai macam konflik yang berbenturan dengan nilai-nilai tradisional. Hal tersebut biasanya diawali dengan adanya perubahan teknologi (kebudayaan materiil) yang lebih cepat berkembang dibandingkan dengan perubahan pada nilai-nilai, norma-norma, kepercayaa, serta pola perilaku dan pola berpikir yang menjadi alat pengatur manusia dalam hidup bermasyarakat (Ogburn, 1950).

\section{Metode}

Penelitian ini merupakan penelitian kualitatif (qualitative research) dengan menggunakan pendekatan studi kasus (case study). Studi ini merupakan tehnik untuk mempelajari culture lag dalam program Penerimaan Peserta Didik Baru (PPDB) yang dilakukan secara online dengan sistem zonasi di Sekolah Menengah Atas Negeri 2 Sukoharjo Tahun Pelajaran 2018/2019.

Sumber data primer dalam penelitian ini merupakan semua perkataan yang penting atau tindakan dari informan yaitu peserta didik baru, orang tua peserta didik baru, guru, karyawan, serta stakeholders dalam pelaksanaan Penerimaan Peserta Didik Baru (PPDB) online dengan sistem zonasi di Sekolah Menegah Atas Negeri 2 Sukoharjo. Selain dari semua itu merupakan sumber data sekunder, diantaranya dokumentasi berupa data tertulis, foto dan data statistik yang diperoleh dari pihak-pihak terkait. 
Teknik pengambilan sampel menggunakan cara purposive non-probability sampling, karena peneliti menentukan informan sesuai kriteria mengenai cultural lag dalam Penerimaan Peserta Didik Baru (PPDB) online dengan sistem zonasi di Sekolah Menengah Atas Negeri 2 Sukoharjo.

Variasi informan ditentukan berdasarkan syarat dan ketentuan yang berlaku dalam sistem zonasi bagi peserta didik baru dalam mengikuti Penerimaan Peserta Didik Baru (PPDB) online sistem zonasi. Informan yang peneliti gali informasinya ditentukan berdasarkan kebutuhan peneliti dalam menggali data. Peneliti terus menggali informasi kepada informan yang sesuai kriteria dalam penelitian. Kriteria yang penulis tentukan kepada informan berupa informan kunci, informan utama dan informan pendukung.

Teknik pengumpulan data dilakukan dengan cara pengamatan (observasi), wawancara mendalam (in-depth interview) dan dokumentasi. Triangulasi sumber dalam penelitian ini digunakan untuk mengumpulkan data yang bersifat informatif mengenai cultural lag dalam program Penerimaan Peserta Didik Baru (PPDB) yang dilakukan secara online dengan sistem zonasi, oleh karena itu peneliti menggali data sekaligus menguji keabsahan serta kredibilitas data yang peneliti dapatkan langsung dari peserta didik baru, guru, karyawan dan semua pihak yang terlibat.

Analisis data dalam penelitian ini merupakan siklus interaktif dengan beberapa tahap, yaitu pengumpulan data, reduksi data, penyajian data dan verifikasi. Proses analisa data sekaligus menyeleksi data, dalam penelitian ini dilakukan dengan cara menyederhanakan keterangan yang ada.

Dalam siklus interaktif, peneliti terus bergerak diantara empat tahap sumbu kumparan selama pennggalian data berlangsung, tahapan tersebut diantaranya adalah reduksi, penyajian dan penarikan kesimpulan atau verifikasi. Kegiatan ini ditetapkan ke dalam penelitian ini, berarti data dikumpulkan dari proses wawancara, observasi dan dokumentasi.

Kemudian direduksi dengan cara menyederhanakan dan menyeleksi data yang sesuai dengan permasalahan. Setelah melalui proses reduksi, data yang sudah terseleksi peneliti sajikan dan analisis dalam penyajian data. Data yang terakhir setelah data tersusun rapi dan dianalisis dengan benar, lalu tahapan selanjutnya adalah verifikasi atau penarikan kesimpulan.

\section{Hasil dan Pembahasan}

Hasil dari penelitian ini menunjukkan bahwa ketidaksiapan peserta didik baru dalam menghadapi program Penerimaan Peserta Didik Baru (PPDB) yang dilakukan secara online dengan sistem zonasi. Hal tersebut dapat dilihat dari jumlah pendaftar peserta didik baru di Sekolah Menengah Atas Negeri 2 Sukoharjo mayoritas melakukan pendaftaran secara online di sekolah padahal sistem pendaftaran online bisa dilakukan di luar sekolah. Persiapan terkait berupa perangkat utama yaitu komputer, Sumber Daya Manusia juga jaringan internet juga masih banyak ditemukan kelemahan. Dengan minimnya sosialisasi mengenai petunjuk pengisian program Penerimaan Peserta Didik Baru (PPDB) online, fakta di lapangan menunjukkan masih banyak ditemukan kesalahan dalam pengisian data.

Masih banyak ditemukan paradigma mengenai sekolah favorit yang kemudian berpengaruh pada pemilihan Sekolah Menengah Atas sebagai sekolah tujuan untuk melanjukan pendidikan di jenjang Sekolah Menengah Atas. Sedangkan sistem zonasi yang sudah berlaku sejak Tahun Pelajaran 2017/2018 ini bertujuan untuk menghilangkan 
kastanisasi dalam proses Penerimaan Peserta Didik Baru (PPDB) online.

Hasil penelitian ini menunjukkan masih banyak peserta didik baru yang mengalami kesalahan masuk Sekolah Menengah Atas yang tidak sesuai dengan keinginannya dan kemampuannya. Dalam komponen penilaian terkait ketentuan tambahan nilai prestasi masih banyak ditemukan kerancuan. Ada beberapa peserta didik baru yang merasa dirugikan karena memiliki sertifikat tertentu, namun sertifikat tersebut tidak dapat diakui sebagai penambahan nilai prestasi terkait lembaga yang mengeluarkan.

Untuk menganalisis permasalahan yang penulis angkat dalam penelitian mengenai cultural lag dalam program Penerimaan Peserta Didik Baru (PPDB) yang dilakukan secara online dengan sistem zonasi di Sekolah Menengah Atas Negeri 2 Sukoharjo, penulis menggunakan teori cultural lag yang dikemukakan oleh William F Ogburn.

Konsep cultural lag yang disampaikan oleh Ogburn mengacu pada adanya kecenderungan dari habit masyarakat dalam kehidupan sosialnya dan pola-pola yang menjadi unsur pengatur kehidupan masyarakat (nilai-nilai, norma-norma, kepercayaan) yang tertinggal di belakang (lag behind) dengan perubahan materiil (ilmu pengetahuan dan tekonologi) yang sudah lebih berkembang terlebih dahulu. Hal itulah yang mengakibatkan terjadinya perubahan sosial. Sosial change yang terjadi biasanya ditandai dengan adanya ketegangan dan ketimpangan antara kebudayaan materiil dengan kebudayaan imateriil. Di dalam masyarakat tertentu ini menimbulkan konflik yang cukup signifikan, namun bagi masyarakat tertentu ini hanya menimbulkan perbedaan perspektif yang mana kedua unsur kebudayaan masih dapat berjalan meskipun tidak sejajar dan beriringan (Ogburn, 1964).

Sekolah Menengah Atas Negeri 2 Sukoharjo adalah lembaga pendidikan tingkat lanjut dibawah Dinas Pendidikan Provinsi Jawa Tengah. Dengan demikian, kebijakan dan tata peraturan yang digunakan dalam proses penyelenggaraan proses pendidikan merujuk pada kebijakan Dinas Pendidikan Provinsi Jawa Tengah termasuk didalamnya proses Penerimaan Peserta Didik Baru (PPDB) sistem zonasi yang dilakukan secara online. Proses rekrutmen peserta didik baru ini tidak sama dengan proses penerimaan peserta didik baru sebelumnya.

Perbedaan tersebut nampak dalam sistem yang dihadirkan dalam membantu proses seleksi yaitu munculnya tambahan fitur zonasi didalamnya. Sistem zonasi ini berguna untuk memetakan lokasi tempat tinggal calon peserta didik baru. Sistem zonasi dalam Penerimaan Peserta Didik Baru (PPDB) di Sekolah Menengah Atas Negeri 2 Sukoharjo mewajibkan sekolah menerima calon peserta didik baru yang bertemoat tinggal dalam radius zona terdekat sekolah dan hal ini dijadikan pertimbangan pertama dalam menerima peserta didik baru.

Kompleksitas respon peserta didik baru terhadap program Penerimaan Peserta Didik Baru (PPDB) online dengan sistem zonasi sebenarnya bisa dipahami sebagai sebuah gejala "kesenjangan budaya" (cultural lag).

Menurut Ogburn (1964) yang mencetuskan teori ini, teknologi adalah mesin utama penggerak kemajuan namun senantiasa berbenturan dengan respon social terhadapnya.

a. Bertumpu pada asusmsi dasar "middle technological determinism", William F Ogburn menyatakan bahwa kesenjangan budaya terjadi pada tahapan akhir dari empat tahapan perkembangan teknologi, yaitu: 
penemuan, yaitu tahapan dimana teknologi pertama kali diciptakan.

b. Akumulasi, yaitu proses pertumbuhan dan perkembangan teknologi.

c. Difusi yaitu proses pertukaran dan pergulatan gagasan seputar teknologi yang pada gilirannya memunculkan temuan-temuan baru.

d. Penyesuaian diri, yaitu tahapan di mana aspek-aspek non material dari budaya merespon temuan-temuan teknologi tersebut. Keterlambatan respon budaya non material inilah yang menyebabkan munculnya kesenjangan budaya.

Uraian Ogburn tersebut tepat menggambarkan realitas dalam sistem Penerimaan Peserta Didik Baru (PPDB) online dengan sistem zonasi dan respon sosial terhadapnya. Pada saat sistem online dilibatkan dalam dunia pendidikan khususnya seleksi penerimaan peserta didik baru, maka persoalan penyesuaian diri antara calon peserta didik baru dan sistem online mencuat ke permukaan. Persoalan yang tampak dalam Penerimaan Peserta Didik Baru (PPDB) online sistem zonasi adalah ketidaksiapan calon peserta didik baru dalam mengikuti proses seleksi, banyak ditemukan hambatan terkait pengisian data dalam fitur-fitur yang telah disediakan di sistem.

Banyak ditemukan kesalahan dalam pengisian pemilihan jurusan dan pemilihan sekolah berdasarkan zonasi. Pada pemilihan jurusan di Sekolah Menengah Atas banyak siswa yang terpaku pada satu jurusan saja, tanpa mempertimbangkan nilai dari hasil Ujian Nasional yang didapat. Sedangkan sistem tidak bisa menganalisa lebih jauh mengenai pemilihan jurusan yang sesuai dengan kemampuan ataupun nilai ujian nasional siswa, yang kemudian berujung pada kesalahan dalam pemilihan jurusan ketika diterima ataupun terlempar dari sistem seleksi
Penerimaan Peserta Didik Baru (PPDB) online dan harus mendaftarkan kembali di sekolah swasta.

Permasalahan ini terus berlanjut hingga proses Penerimaan Peserta Didik Baru (PPDB) online dengan sistem zonasi berakhir. Hasil penelitian di lapangan ditemukan cukup banyak siswa yang akhirnya mengundurkan diri sebagai calon peserta didik baru walaupun peserta didik baru tersebut dinyatakan diterima pada sekolah pilihan. Minimnya sosialisasi yang didapatkan calon peserta didik dalam proses penyesuaian diri terhadap penggunaan program Penerimaan Peserta Didik Baru (PPDB) online dengan sistem zonasi menjadi salah satu faktor penyebab terjadinya cultural lag.

\section{Kesimpulan}

Sekolah Menengah Atas Negeri 2 Sukoharjo adalah lembaga pendidikan tingkat lanjut yang berada di Kabupaten Sukoharjo dan di bawah naungan Dinas Pendidikan dan Kebudayaan Provinsi Jawa Tengah. Pada tahun ajaran 2018/2019 termasuk sekolah yang menggunakan sistem seleksi Penerimaan Peserta Didik Baru (PPDB) online dengan sistem zonasi terobosan dari Kementerian Pendidikan dan Kebudayaan Republik Indonesia. Sistem seleksi Penerimaan Peserta Didik Baru (PPDB) online dengan sistem zonasi merupakan hal baru dalam perekrutan peserta didik baru, dimana nilai Ujian Nasional bukan penentu peserta didik baru untuk dapat diterima di sekolah yang diinginkan. Namun jarak radius tempat tinggal yang bersangkutan yang menjadi syarat dan ketentuan dalam proses Penerimaan Peserta Didik Baru (PPDB) online.

Hasil riset menunjukkan bahwa pelaksanaan Penerimaan Peserta Didik Baru (PPDB) online sistem zonasi banyak terdapat permasalahan serta hambatan. Hal ini terjadi karena kurangnya sosialisasi dan ketidaksiapan calon peserta didik baru serta 
orang tua dalam menghadapi perubahan sistem pendidikan yang selalu mengalami perubahan yang cukup signifikan.

Ketidaksiapan masyarakat dalam menghadapi perubahan sistem baru, utamanya yang berkaitan dengan kebudayaan materiil (ilmu pengetahuan dan teknologi), termasuk dalam kajian cultural lag. Dimana terdapat kesenjangan yang cukup signifikan antara aspek materiil (ilmu pengetahuan dan teknologi). dengan aspek imateriil (kebiasaan serta pola perilaku).

\section{Saran}

1. Bagi pemerintah pusat, akan lebih baik melakukan evaluasi perbaikan dalam mempersiapkan Penerimaan Peserta Didik Baru (PPDB) online dengan sistem zonasi tahun pelajaran berikutnya agar sistem dapat berjalan lebih maksimal. Disamping itu, merencanakan dan menerbitkan ketentuan perundang-undangan tentang Penerimaan Peserta Didik Baru (PPDB) online dengan sistem zonasi lebih awal, dengan tujuan untuk memberikan rentang waktu yang cukup bagi pemerintah daerah dan sekolah untuk menyesuaikan dengan peratuan perundang-undangan yang baru.

2. Bagi pemerintah daerah penyelenggara kebijakan, akan lebih baik apabila mengadakan sosialisasi yang massif kepada satuan-satuan pendidikan maupun satuan kerja yang terkait dengan Penerimaan Peserta Didik Baru (PPDB) online sebelum program tersebut dilaksanakan. Sehingga peserta didik baru beserta orang tua tidak mengalami kendala yang berarti dalam mengikuti setiap tahapan program Penerimaan Peserta Didik Baru (PPDB) online dengan sistem zonasi yang berlaku.

3. Bagi sekolah penyelenggara Penerimaan Peserta Didik Baru (PPDB) online, lebih baik apabila semua yang terkait dengan program Penerimaan Peserta Didik Baru (PPDB) online dengan sistem zonasi dipersiapkan secara matang, antara lain Sumber Daya Manusia dan perangkat komputer sebagai pendukung jalannya sistem pendidikan nasional secara online.

4. Bagi orang tua atau wali peserta didik baru, akan lebih baik bila selalu mengikuti dan memperbaharui informasi-informasi terkait perubahan regulasi dalam sistemsistem yang ada dalam dunia pendidikan saat ini.

\section{Daftar Pustaka}

Juknis PPDB SMA Negeri dan SMK Negeri Jateng Tahun Pelajaran 2018/2019.

Munirah, 2015. Sistem Pendidikan di Indonesia : Antara Keinginan dan Realita. Jurnal Auladuna, Volume 2, Nomor 2.

Ogburn, William F. 1950. Social Change, With Respect to Culture and Original Nature. New York : Viking

Ogburn, William F and Mayer F Nimmkoff. 1964. Sociology. Boston: A Pfeffer And Simmons International University Edittion, Toughton Miffilin Company

Peraturan Menteri Pendidikan dan Kebudayaan Nomor 17 Tahun 2017 Tentang Penerimaan Peserta Didik Baru (PPDB).

Rosdiana, Weni dan Hermin Aprilia Lestari. 2017. Implementasi Kebijakan Penerimaan Peserta Didik Baru (PPDB) Di SMA Negeri 4 Kota Madiun Tahun 2017. Jurnal Fakultas Ilmu Sosial dan Hukum. Universitas Negeri Surabaya.

Soetarno, 2004. Sumber Daya Pendidikan Dengan Pendekatan Sistem. Makalah Pendidikan. Surakarta : Universitas Muhammadiyah Surakarta. 
Supardan, Dadang. 2009. Pengantar Ilmu

Sosial : Sebuah Kajian Pendekatan

Struktural. Jakarta : Bumi Aksara.

Sztompka, Piotr. 2004. Sosiologi Perubahan

Sosial. Jakarta: Prenada Media Group.

Undang-Undang Republik Indonesia Nomor

20 Tahun 2003 Tentang SISDIKNAS.

Website resmi Kementerian Pendidikan dan

Kebudayaan Republik Indonesia

https://www.kemdikbud.go.id/ 